\title{
Development of an Ultrasensitive Electrochemical Method for Copeptin Content Determination
}

\author{
Yan Yang ${ }^{1}$, Songtao Gao ${ }^{1}$, Jing Yang ${ }^{1}$, Wei Yang ${ }^{1}$ and Xiaoling Sun ${ }^{2, *}$ \\ ${ }^{1}$ The Department of Cardiology, Heilongjiang Province Nangang Hospital, No.402 Guogeli St, \\ Harbin, Heilongjiang, 150001 P.R. China \\ 2 The Clinical Laboratory of Digest, Heilongjiang Province Nangang Hospital, No.402 Guogeli St, \\ Harbin, Heilongjiang, 150001 P.R. China \\ *E-mail: xiaolingsun58@qq.com
}

doi: $10.20964 / 2017.07 .36$

Received: 16 March 2017 / Accepted: 2 May 2017 / Published: 12 June 2017

\begin{abstract}
Coronary heart disease, coronary syndrome and other cardiovascular diseases are globally predominant fatal conditions, although they can be prevented to a large extent. The determination of proper therapeutic options can be facilitated by copeptin level detection. A nanocomposite of reduced graphene oxide $(\mathrm{RGO})$ and titania $\left(\mathrm{TiO}_{2}\right)$ was employed to fabricate a tag-free biosensor in this contribution. To specifically recognize and detect copeptin, this $\mathrm{RGO}-\mathrm{TiO}_{2}$ nanocomposite was functionalized with antibodies that are conjugated by protein (horseradish peroxidase). This biosensor exhibits enhanced biosensing traits for copeptin determination. Small-scale diagnostic equipment could be developed on the basis of this Ab-copeptin/RGO- $\mathrm{TiO}_{2} / \mathrm{ITO}$ immunoelectrode.
\end{abstract}

Keywords: Cardiovascular diseases; Immunosensor; Copeptin; Graphene oxide; Titania

\section{FULL TEXT}

(C) 2017 The Authors. Published by ESG (www.electrochemsci.org). This article is an open access article distributed under the terms and conditions of the Creative Commons Attribution license (http://creativecommons.org/licenses/by/4.0/). 